\title{
Water quality in a complex geomorphological lagoon at the Gulf of Mexico, based in recent and compared with information 30 years ago
}

\begin{abstract}
The physicochemical composition of the tropical coastal water lagoons is result of several factors: sedimentary, fluvial, marine, biological and currently anthropogenic, which vary in space and time. To understand their tendency to change it is necessary to have a sufficient database. Take in account, the present study aimed to estimate the change in physicochemical or water quality in a coastal lagoon of the Gulf of Mexico based on data recorded from the 1970s of the last centuries until 2016-2018; likewise, the analysis was supported with a trophic index to estimate its degree of impact. The results shown the increase in orthophosphates, total phosphorus and chlorophyll "a" content that with the support of Carlson's trophic index defined a coastal lagoon as natural eutrophicin the 1970s and between 2016-18 to cultural hypertrophy, results of peripheral settlements.
\end{abstract}

Keywords: Trophiclevel, tropical coastallagoon, Mexico
Volume 7 Issue 5 - 2018

\section{Guadalupe de la Lanza, Salvador Hernández Pulido}

Instituto de Biología universidad Nacional Autónoma de México, Mexico

Correspondence: Guadalupe de laLanza, Instituto de Biología, Universidad Nacional Autonoma de Mexico, Ciudad Universitaria S/N, 045 I0, Ciudad de Mexico, Mexico, Tel 0155 56229I32, Fax 0 I 55 55500I64, Email gdlle@unam.mx

Received: August 21, 2018 | Published:September 07, 2018

\section{Introduction}

The river water arrives coastal systems having a composition depends edaphology watershed, generating a gradient between freshwater and marine through tides which may be local variables and amplitudes. To this must be added the climate and its variability, which results in different concentrations in dissolved chemical compounds in water both spatially and temporally, with intervals that can be considered normal, as long as knowledge it has such variation and not subject to official regulations requiring specific concentrations and do not recognize the environmental change. A stranger to the nature of coastal environments factor is the influence of anthropogenic activities, which go beyond the normal range of physicochemical conditions of water and tend to deleterious conditions not only to aquatic organisms, but for men as well. There are chemical determinations practices that define the physicochemical or water quality; these are: temperature, salinity, $\mathrm{pH}$, dissolved oxygen and their saturation, chemical oxygen demand or COD (measuring the organic load) and so-called nutrients (salts of nitrogen such as ammonia, nitrites, nitrates, total nitrogen that includes organic) and orthophosphates with total phosphorous (which also includes organic). ${ }^{1}$

To determine the physicochemical characteristics of the water of a lagoon and its tendency to increase, it is necessary to have previous information to compare their condition, modification or impact.If it not possible to have the necessary background of a coastal lagoon, at least look information systems or other surrounding lagoons in the country. It is noteworthy that the regulations previously NOM ECOL 001 (Mexican Norm) and now NOM 001-SEMARNAT-2003, ${ }^{2}$ is unfortunately developed for wastewater discharges and even treated to induce misinterpretations and serious mistakes.

In a variation of full scale in the chemical parameters, now you have to take into consideration the influence of climate change also affects the coast by rising sea levels and declining contributions from rivers discharging into the area coastal result of its decline and damming for agricultural purposes and urban services in increments of substances harmful to ecosystems. Therefore, it is necessary to make adequate simples to each water body spatial and temporal planning to determine the extent of natural and influence changes as well as anthropogenic factors affecting water quality and treatment capacity.

In Mexico there are just over 125 coastal systems ${ }^{3}$ which are influenced by various anthropogenic activities local and waterways downloads from the origin of its basin until the arrival coastal systems, bringing a wide variety of contaminants collected in its path organic and inorganic materials such as nitrogen and phosphorus, fertilizers, biocides, metals, general trash where plastics include, among others, which have differences in the degradation time and even its stay in pelagic or benthic environment (flora and fauna) and sediments lagoons, estuaries and bays (marine environments) even in the ocean. ${ }^{4}$

Based on the above was chosen to Mandinga lagoon, Ver., In order to determine their conditions and physicochemical changes or quality of water in a in rains (August 2016) and another in drought (March 2018) considering not only two climatic seasons, but also the increase in population; it will assess water quality by natural climatic effects of season and those caused by human activities settled on its periphery with their downloads on the lagoon system. Likewise compare with previous studies since the early 1970s as Vazquez, ${ }^{5}$ Contreras, ${ }^{6}$ Aguilar, ${ }^{7}$ de la Cruz,${ }^{8}$ CONABIO,${ }^{9}$ Contreras, ${ }^{10}$ Contreras Espinosa, ${ }^{11}$ BarreiroGüemez, ${ }^{12}$ Herrera Silveira, ${ }^{13}$ among others.

\section{Study area}

Mandinga Lagoon is located between $19^{\circ} 00$ 'and $19^{\circ} 06^{\prime}$ north latitude and meridians $96^{\circ} 02$ 'and $96^{\circ} 06^{\prime}$ ' west (Figure 1) long with an area of 3,250ha and climate: AW2 (w) (i ') w'. ${ }^{14}$ The rainfall is $1500 \mathrm{~mm}$ per year, the rainfall occurs in the months of June to October and the drought season from November to May. It has a north-south orientation while the nearby coast adopts a northwest-southeast direction, forming the atoll of Antón Lizardo. To the northwest lagoon system, it is separated from the sea by a barrier of sand dunes. It is associated with Jamapa River, which originates with snowmelt from Pico de Orizaba, that runs $150 \mathrm{~km}$; also receives several small tributaries and Jamapa River that flows into the Gulf of Mexico.

\section{Methodology}

In August 2016 eight were chosen sites sampling, same that were considered in the collection March 2018 (Figure 1). Sampling 
consisted of in situ determination: temperature, salinity, $\mathrm{pH}$, dissolved oxygen and their saturation and turbidity, recorded in the first five to $10 \mathrm{~cm}$ of the surface and deep as the depth and through the computer HIDROLAB YSI 556 MPS.

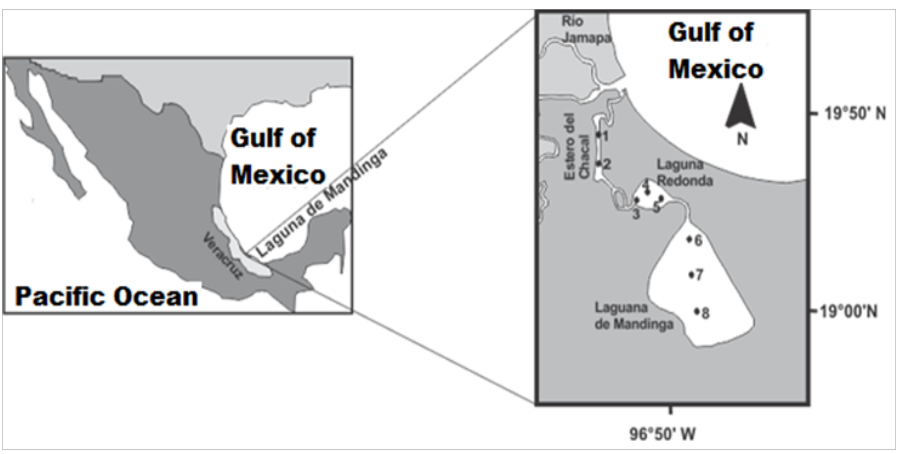

Figure I Location of Mandinga Lagoon, Veracruz, Mexico and sampling sites.

In addition, water samples were collected for determination of chlorophyll "a", nutrients to conserved refrigerated at $4^{\circ} \mathrm{C}$ in the laboratory, as recommended by Strickland and Parsons ${ }^{15}$ and the APHA. ${ }^{16}$ Likewise, techniques, the results were compared with previous information from 1980 to 2013 in order to estimate possible changes in physical chemistry due to peripheral human settlements in the space between the decade of the 80's and 2013. In addition, the trophic status of the lagoon was calculated through trophic index by Carlson. ${ }^{17}$

\section{Results and discussion}

Temperatures were in August, especially in surface between 29.78 and $31.11^{\circ} \mathrm{C}$, interval with a little difference at the bottom between 29.13 to $30.94^{\circ} \mathrm{C}$. In April surface interval was between 25.13 to $27.11^{\circ} \mathrm{C}$ and at the bottom of 24.91 to $25.89^{\circ} \mathrm{C}$; marking a time difference that is greater in lower rainfall and dry, respectively. Intervals have been recorded by other authors since the early 80 s of last century, considered typical of a Mexican coastal lagoon of the tropical latitude, dependent to the epoch year.

Salinity in August (rainy) interval ranged from 8.61 to 18.11ups result of the location of the sampling site with highs in marine intercommunication, a place where the influence of Jamapa River was recorded in conjunction with input seawater by bottom; with lower salinity sites sampling that was in the middle of the lagoon. In April (dry) increased the variation of salinity more than doubled, with the maximum in marine mouth (31.64-31.78 ups) with lower and homogeneous in the other stations in both surface and deep levels (2936-27.65ups). 28 years ago, in the months of September-October and May, as Bornn ${ }^{18}$ determined a saline range from 4.58 to 29.1 ups in the rainy and dry, respectively. Amador and Cabrera ${ }^{19}$ determined a range of salinity from 3.1 to 33 ups, Morales ${ }^{20}$ noted that the haline variation ranged from 13.9 to 34.6 ups in the dry season, like other authors like Gomez $^{21}$ and Castan $^{22}$ intervals. This conservative parameter depends on the rains, the dry season, the influence of river discharge and therefore the geomorphology and location of the sampling site.

The dissolved oxygen content in both samples were heterogeneous result of being a factor by non conservative effects of photosynthesis and respiration, not by the epoch, with the lower scarcely contained in at the bottom. As for the percent saturation in the rainy season was estimated at $111.3 \%$ to $43.7 \%$ with a punctual site where the lowest level site was considered risky for biota; He noted at the dryness the saturation range between 107.8 to $112.1 \%$ with greater uniformity, which denoted higher photosynthetic activity. a single low concentration was recorded at station 2 (Estero el Conchal) with $43.7 \%$ saturation in the bottom, critical level for the survival of benthic organisms. Cabrera ${ }^{19}$ determined a level range between 1.7 to 9mg/L. like other authors like Gomez ${ }^{21}$ and Castan ${ }^{22}$ intervals.

The $\mathrm{pH}$ range was between 7.4 and 8.8 , levels considered normal for such coastal environments. For its $\mathrm{Cabrea}^{19}$ reported a $\mathrm{pH}$ range between 5.9 (acidic condition) to 8.3 (alkaline condition), result of the importance of geomorphology and time of sampling which involves the influence of diurnal variation in phytoplankton activity and respiration of plankton.

As nitrates and nitrites in both samples ranged between undetectable (0-M) up to 1.23uM until 0-14 (micromoles) concentrations considered low; even like determined by Bornn ${ }^{18}$ and Contreras ${ }^{10}$; more than 30 years and 20 years ago respectively, which means the maintenance of good environmental status, regarding these nutrients.

The predominant form ammonia was specifically in April where sampling recorded $>12 \mathrm{uM}$. few differences in the concentrations of total nitrogen in the two sampled months, highlighting in August and April contents were approximately twice in both sites 7 and 8 (lagoon center) at surface and bottom, compared with the other stations.

The concentrations determined by Bornn ${ }^{18}$, Contreras ${ }^{10}$ and Barreiro $^{12}$ determined that the nutrients were more abundant in the rainy season, where nitrates ranged between 0.7 and $3.4 \mu \mathrm{M}$ and ammonium, 2 to $8 \mu \mathrm{M}$; Similar amounts within the given range in 2012-2013. Accordingly, these nitrogen nutrients define the lagoon without problems on water quality.

The range of variation of orthophosphates and total phosphorus (Table 1) (Table 2) showed lower levels in April were considered within normal variation for coastal systems; However, in August sites 7 and 8 (middle of the lagoon) were high that exceeded recorded as normal in coastal lagoons. Comparatively, in 1982 Bornn $^{18}$ quantificate lower contents both orthophosphates $(1.7-2.8 \mu \mathrm{M})$ and total phosphorus $(2-12 \mu \mathrm{M})$ and $^{10}$ estimated between 0.01 to $5.0 \mu \mathrm{M}$ orthophosphates and 5 to $10 \mu \mathrm{M}$ average total phosphorus; in 2002 Barreiro $^{12}$ determined a phosphate content, between 0.2 and $7 \mu \mathrm{M}$. According to these authors the levels indicated a satisfactory state of ecological health, but the determination between 2012-2013 in the center of the Mandiga Lagoon (7 and 8 sites), exceeded more than doubled on average, probably due to different chemical factors between the water column and sediment, ${ }^{23}$ although the contribution of wastewater is not discarded of the human settlements in peripheral villages.

The contents of chlorophyll "a", were heterogeneous in space and time; in August which amounted to $56.4 \mathrm{mg} / \mathrm{m}^{3}$ at a site 5 (Laguna La Redonda) and even station 3 with $34.1 \mathrm{mg} / \mathrm{m}^{3}$ concentrations that can be slightly elevated compared to the rest of the sampled sites. Amador ${ }^{19}$ quantify levels of this pigment between $54.19 \mathrm{mg} / \mathrm{m}^{3}$ and $40.27 \mathrm{mg} / \mathrm{m}^{3}$ in May and August respectively. According Barreiro ${ }^{12}$ determined highest concentration of chlorophyll a, $\left(22 \pm 2.3 \mathrm{mgm}^{-3}\right)$ recorded in the dry season, which corresponds to the spring; while the lowest content $\left(3.4 \pm 1.3 \mathrm{mgm}^{-3}\right)$ occurred during the dry season (April) too.

Based on the Carlson index ${ }^{17}$ trophic level of Mandinga Lagoon was heterogeneous in space and time, ranging from eutrophic by phosphorus and eutrophic hypertrophic for chlorophyll content "a", as 
presented in Tables 1, Tables 2 and Tables 3. However those categories, the category would be within natural eutrophication and certain sites can be uncertain because of the wide variation of the parameters used sampled cultural eutrophication.

in this study considered normal and in the case of using these indices,

Table I August 2016 sampling parameters of water quality of mandinga lagoon

\begin{tabular}{|c|c|c|c|c|c|c|c|c|c|c|c|c|c|c|c|}
\hline Site & Prof & Hour & Prof & Temp & Sal & OD & Sat OD & pH & $\mathrm{PO}_{4}$ & PT & $\mathrm{NH}_{4}$ & $\mathrm{NO}_{2}$ & $\mathrm{NO}_{3}$ & NT & $\begin{array}{l}\text { Chlorophyll } \\
\text { "a" }\end{array}$ \\
\hline & & & CM & ${ }^{\circ} \mathrm{C}$ & UPS & $\mathrm{mg} / \mathrm{L}$ & $\%$ & & uM & uM & uM & uM & uM & uM & $\mathrm{mg} / \mathrm{m}^{3}$ \\
\hline \multirow[t]{2}{*}{ I } & SUP & $12: 19$ & 183 & 29.78 & 14.49 & 6.75 & 95.7 & 8.76 & 1.29 & 9.35 & 7.14 & 0.07 & 0.07 & 22.86 & 4.70 \\
\hline & BOTT & & & 29.13 & 16.00 & 6.25 & 85.1 & 8.42 & 3.87 & 14.84 & 9.29 & 0.14 & 0.00 & 25.00 & \\
\hline \multirow[t]{2}{*}{2} & SUP & $11: 53$ & 152 & 30.49 & 14.57 & 5.22 & 73.8 & 8.2 & 6.13 & 9.35 & 8.57 & 0.29 & 0.00 & 25.71 & 7.64 \\
\hline & BOTT & & & 29.33 & 11.45 & 3.16 & 43.7 & 7.5 & 8.06 & 12.58 & 9.29 & 0.36 & 0.00 & 27.86 & \\
\hline \multirow[t]{2}{*}{3} & SUP & ||$: 2 \mid$ & 152 & 30.73 & 10.87 & 5.79 & 81.7 & 8.2 & 3.55 & 8.06 & 7.86 & 0.21 & 0.00 & 24.29 & 34.1 \\
\hline & вОTТ & & & 30.01 & 12.31 & 5.78 & 81.4 & 8.0 & 3.87 & 12.26 & 8.57 & 0.50 & 0.00 & 27.14 & \\
\hline \multirow[t]{2}{*}{4} & SUP & $11: 08$ & 152 & 31.11 & 10.98 & 6.09 & 87.8 & 8.2 & 5.81 & 9.03 & 6.43 & 0.14 & 0.00 & 21.43 & 2.9 \\
\hline & BOTT & & & 30.44 & 11.00 & 5.63 & 86.0 & 7.9 & 6.13 & 11.61 & 10.00 & 0.43 & 0.00 & 25.00 & \\
\hline \multirow[t]{2}{*}{5} & SUP & $10: 53$ & 152 & 31.08 & 10.97 & 6.01 & 86.8 & 8.5 & 4.19 & 8.39 & 7.86 & 0.21 & 0.00 & 24.29 & 56.4 \\
\hline & BOTT & & & 30.15 & 9.81 & 4.65 & 62.3 & 8.2 & 5.48 & 10.97 & 8.57 & 0.29 & 0.00 & 27.86 & \\
\hline \multirow[t]{2}{*}{6} & SUP & $10: 16$ & 335 & 30.65 & 10.85 & 6.46 & 91.0 & 7.9 & 4.84 & 10.32 & 8.57 & 0.36 & 0.00 & 26.43 & 31.7 \\
\hline & BOTT & & & 29.96 & 11.43 & 5.67 & 75.6 & 7.5 & 7.74 & 13.23 & 9.29 & 0.57 & 0.00 & 28.57 & \\
\hline \multirow[t]{2}{*}{7} & SUP & $9: 52$ & 213 & 30.45 & 10.78 & 6.18 & 85.9 & 7.79 & $18.7 \mid$ & 21.94 & 7.14 & 1.07 & 0.00 & 50.00 & 18.2 \\
\hline & BOTT & & & 30.35 & 11.28 & 4.64 & 65.7 & 7.39 & 30.00 & 33.23 & 7.86 & I.14 & 0.00 & 53.57 & \\
\hline \multirow[t]{2}{*}{8} & SUP & $9: 31$ & 189 & 30.95 & 8.61 & 7.89 & 111.3 & 7.6 & 20.97 & 24.19 & 12.14 & 1.14 & 0.00 & 50.00 & 12.3 \\
\hline & BOTT & & & 30.94 & 11.31 & 6.08 & 87.1 & 7.4 & 34.84 & 37.42 & 12.86 & 1.29 & 0.00 & 52.14 & \\
\hline
\end{tabular}

Table 2 April 2018 sampling parameters of water quality of mandinga lagoon

\begin{tabular}{|c|c|c|c|c|c|c|c|c|c|c|c|c|c|c|c|}
\hline Site & Prof & Hour & Prof & Temp & Sal & OD & Sat OD & $\mathrm{pH}$ & $\mathrm{PO}_{4}$ & PT & $\mathrm{NH}_{4}$ & $\mathrm{NO}_{2}$ & $\mathrm{NO}_{3}$ & NT & Chlorophyll "a" \\
\hline & & & CM & ${ }^{\circ} \mathrm{C}$ & UPS & $\mathrm{mg} / \mathrm{L}$ & $\%$ & & uM & $\mathrm{uM}$ & $\mathrm{uM}$ & $\mathrm{uM}$ & $\mathrm{uM}$ & $\mathrm{uM}$ & $\mathrm{mg} / \mathrm{m}^{3}$ \\
\hline \multirow[t]{2}{*}{ I } & SUP & $10: 20$ & 350 & 25.13 & 31.64 & 7.40 & 108.8 & 7.26 & 3.55 & $\mid 1.61$ & 11.43 & 0.43 & 0.43 & 22.86 & 14.11 \\
\hline & BOTT & & & 24.91 & 31.78 & 6.80 & 101.5 & 7.47 & 5.16 & 12.58 & 13.57 & 0.57 & 2.14 & 27.14 & \\
\hline \multirow[t]{2}{*}{2} & SUP & |l:00 & 250 & 25.85 & 2936 & 7.52 & 112.2 & 7.94 & 4.19 & 10.00 & 11.43 & 0.21 & 0.71 & 25.71 & 12.93 \\
\hline & BOTT & & & 25.40 & 27.65 & 6.88 & 104.2 & 7.96 & 6.13 & 11.29 & 12.14 & 0.29 & 1.43 & 27.86 & \\
\hline \multirow[t]{2}{*}{3} & SUP & $\mid 1: 28$ & 185 & 26.04 & 28.84 & 7.31 & 109.1 & 8.08 & 3.23 & 12.58 & 11.43 & 0.36 & 0.71 & 13.57 & 26.46 \\
\hline & BOTT & & & 25.45 & 27.40 & 6.90 & 104.5 & 8.11 & 3.55 & 13.55 & 12.86 & 0.57 & $\mathrm{I} .43$ & $|5.7|$ & \\
\hline \multirow[t]{2}{*}{4} & SUP & 12:45 & 160 & 26.66 & 28.63 & 7.03 & 106.5 & 8.06 & 3.55 & 21.61 & 11.43 & 0.07 & 0.71 & 18.57 & 12.34 \\
\hline & BOTT & & & 25.89 & 28.78 & 6.90 & 106.2 & 8.13 & 4.19 & 23.87 & 12.14 & 0.21 & 0.71 & 22.86 & \\
\hline \multirow[t]{2}{*}{5} & SUP & | |:47 & 225 & 26.11 & 28.76 & 7.17 & 112.0 & 8.01 & 3.87 & 12.90 & 12.14 & 0.21 & 0.71 & 24.29 & 8.23 \\
\hline & BOTT & & & 25.24 & 28.62 & 6.83 & 108.4 & 8.12 & 4.52 & 13.55 & 12.14 & 0.29 & 0.71 & 27.14 & \\
\hline \multirow[t]{2}{*}{6} & SUP & 12:25 & 350 & 26.10 & 28.08 & 7.41 & 110.6 & 8.18 & 4.52 & 12.90 & 11.43 & 0.36 & 0.71 & 54.29 & 9.40 \\
\hline & BOTT & & & 25.35 & 28.18 & 6.83 & 103.5 & 8.27 & 5.16 & 13.87 & 12.86 & 0.36 & 0.71 & 58.57 & \\
\hline \multirow[t]{2}{*}{7} & SUP & 12:08 & 180 & 26.19 & 28.06 & 8.00 & 119.4 & 8.18 & 3.55 & 12.90 & 9.29 & 0.14 & 0.71 & 47.86 & 11.76 \\
\hline & BOTT & & & 25.2 & 27.99 & 7.40 & $1 \mid 2.1$ & 8.20 & 4.84 & 14.19 & $|0.7|$ & $0.7 \mathrm{I}$ & 1.43 & 52.14 & \\
\hline \multirow[t]{2}{*}{8} & SUP & 13:05 & 180 & 27.11 & 28.92 & 7.02 & 108.0 & 8.10 & 4.19 & 12.90 & 11.43 & 0.21 & 2.86 & 50.71 & 9.40 \\
\hline & BOTT & & & 25.61 & 29.02 & 6.90 & 107.8 & 8.20 & 5.16 & 14.52 & 12.14 & 0.36 & 3.57 & 55.00 & \\
\hline
\end{tabular}

Citation: De la Lanza, Pulido SH.Water quality in a complex geomorphological lagoon at the Gulf of Mexico, based in recent and compared with information 30 years ago. J Aquac Mar Biol. 2018;7(5):253-256. DOI: I0.15406/jamb.2018.07.00216 
Table 3 Criteria application index eutrofizacation(carlson 1977)

\begin{tabular}{lllll}
\hline Trophic class & TSI & $\mathbf{S D}(\mathbf{m})$ & $\mathbf{P}\left(\mathbf{m g} / \mathbf{m}^{3}\right)$ & $\mathbf{C H L} \mathbf{a}\left(\mathbf{m g} / \mathbf{m}^{3}\right.$ \\
\hline & 0 & 64 & 0.75 & 0.04 \\
$\begin{array}{l}\text { Oligotrophic (TSI } \\
<30)\end{array}$ & 10 & 32 & 1.5 & 0.12 \\
& 20 & 16 & 3 & 0.34 \\
& 30 & 8 & 6 & 0.94 \\
Mesotrophic & 40 & 4 & 12 & 2.6 \\
$\begin{array}{l}\text { (30<TSI<90) } \\
\text { Eutrophic }\end{array}$ & 50 & 2 & 24 & 6.4 \\
$(60<$ TSI<90) & 80 & 1 & 48 & 20 \\
& 70 & 0.5 & 96 & 56 \\
$\begin{array}{l}\text { Hipereutrophic } \\
(90<\text { TSI<100) }\end{array}$ & 100 & 0.25 & 192 & 154 \\
\hline
\end{tabular}

\section{Conclusions}

It notes that some physicochemical characteristics or water quality of Mandinga Lagoon have remained for several decades oscillating within normal ranges even with higher concentration called natural eutrophication for coastal area spatiotemporal variations. However, content of orthophosphate, total phosphorus and chlorophyll "a" had increased in specific sites in the peripheries to levels eutrophic or hypereutrophic using index $\mathrm{Carlson}^{17}$ in this case it is possible called cultural eutrophication. This condition may be due to increased population in $1.87 \%$ (SEFIPLAN2016). ${ }^{24}$

\section{Acknowledgements}

None.

\section{Conflict of interest}

The author declares that there is no conflict of interest.

\section{References}

1. De la Lanza Espino G, Gutierrez Mendieta FJ. Intervals of non conservative parameters in aquatic coastal system of Mexico. Hidrobiológica. 2017;27(3):369-390.

2. NOM ECOL 001 and now 001-SEMARNAT. Mexican Official Standard NOM-001-SEMARNAT-1996.2003. Secretary of Environment, Fisheries and Natural Resources. Official Mexican Norm. 2003.

3. Lankford RR. Coastal lagoons of Mexico. Their origin and Classification, pp. 182-215. In: Wiley M editor. Estuarine Processes. Academic Press Inc, New York. 1977; 2: 428p.

4. Botello V, Villanueva S, Leon FDN. Evaluation of the presence of microplastic and metals in surface sediments of Mandinga Lagoon, Ver. 2018.

5. Vazquez GF. Physiochemical of Mandinga Lagoon, the River Jamapa and Mixing Zone, Ver., Mexico. Doctoral thesis. UNAM, Mexico. 1983; $203 p$.

6. Contreras F. The Mexican Coastal Lagoons. Ecological Development Center, Ministry of Fisheries. Mexico. 1985; DF 253p.
7. Aguilar ZJA. Floristic study of a marshy area called Laguna the Apompal in Jamapa, Ver. Professional thesis. Fac. of Sciences, UNAM. 1989; 135p.

8. De la Cruz-Aguero G. A preliminary model of Mandinga Lagoon, Veracruz, Mexico. P. 193-196. In: Christensen V, Pauly D editors. Trophic Models of Aquatic Ecosystems. ICLARM. Conf. Proc. 26, 1993. 390 .

9. CONABIO. Ficha técnica para la evaluación de sitios prioritarios. 2018.

10. Contreras FE, Castañeda O, Torres Alvarado R, et al. Nutrients in coastal lagoons. Journal of Tropical Biology. 1996;44(2): 417-425.

11. Contreras Espinosa F. Mexican Coastal Ecosystem san Update. Universidad Autonoma Metropolitana Iztapalapa. 2010; 514p.

12. Barreiro Güemez MT. Patterns of spatiotemporal variation of chlorophyll a concentration in the estuarine system Boca del Rio Mandinga, Ver. Res. XII National Meeting of the Mexican Society of Planktology. 6-9 May. Xalapa, Veracruz. 2002.

13. Herrera Silveira A, Morales Ojeda SM, Cortez Balam O. Eutrophication in Coastal Ecosystems of the Gulf of Mexico V.1"IntegratedAssessment and Management of the Gulf of Mexico, Large Marine Ecosystem "Global Environmental Facility, United Nations Industrial Development Organization, National Ocean and Atmospheric Administration, Secretariat of Environment and Natural Resources. 2011; 88p.

14. Garcia E. System modifications of Köppen climate classification. Series Book No. 6. Institute of Geography, National Autonomous University of Mexico. 1973; 252p.

15. Strickland JDH, Parsons TR. A Practical Hand Book of Seawater Analysis. Second Bulletin 1972. Fisheries Research Board of Canada. Ottawa. 1972; 310p.

16. APHA. Standard Methods for the Examination of Water and Wastewater. 21st Edition, American Public Health Association / American Water Works Association / Water Environment Federation, Washington DC. 2005;588p.

17. Carlson R. A trophic state index for lakes. In: Limnology and Oceanography. 1977;22(2):361-369.

18. Bornn Bru D, Ruiz Zamites Bonilla RI. Analysis cuantitative of phosphorus in the Laguna de Mandinga, Edo. De Veracruz, Mexico. Final Inform of Social Servicie. Universidad Autónoma Metropolitana Iztapalapa. 1982.

19. Amadordel Angel LE, Cabrera Rodriguez P. Physical parameters of Mandinga Lagoon, Veracruz Mexico. Res. SOMPAC VII. 1994.

20. Morales Castañeda J. Characterization and ecological assessment of ictiofauna in the larval, juvenile and adult stages of Mandinga Lagoon system during the dry season of 2009. Thesis. UNAM Iztacala, $2013 ; 193$ p.

21. Gómez Sánchez JE. Composition and temporal variation community fish in the lagoon system Mandinga, Ver., Mexico from 2007 to 2010. Thesis, UNAM Iztacala. 2013;120p.

22. Castán Aquino Y. Ecological analysis of the zooplankton community Mandinga Lagoon system, Ver., during dry and wet seasons. 20082009 and 2010. Thesis. Iztacala UNAM, 2013; 128p.

23. De la Lanza Espino G, Penie Rodriguez I, Czitrom Baus S. Chemistry of coastal waters, pp 141-180, in de la Lanza Espino G. and Hernandez Pulido S. editors. Atmosphere Biology Society, Management and Law Mexican Coastal Systems. INERENA, WWF, Fundación Gonzalo Río Arronte, P and V. 2011.

24. SEFIPLAN. Municipal Information System. Ministry of Finance and Planning of the State of Veracruz. 2016. 10p. 